Article

\title{
Lobophytones O-T, New Biscembranoids and Cembranoid from Soft Coral Lobophytum pauciflorum
}

\section{Pengcheng Yan ${ }^{1}$, Zhiwei Deng ${ }^{2}$, Leen van Ofwegen ${ }^{3}$, Peter Proksch ${ }^{4}$ and Wenhan Lin ${ }^{1}{ }_{*}$}

1 State Key Laboratory of Natural and Biomimetic Drugs, Peking University, Beijing 100083, China; E-Mail: ypc@bjmu.edu.cn

2 Analytical and Testing Center, Beijing Normal University, Beijing, 100875, China;

E-Mail: dengzw@bnu.edu.cn

3 Netherlands Centre for Biodiversity Naturalis, 2300 RA Leiden, The Netherlands;

E-Mail: leen.vanofwegen@ncbnaturalis.nl

4 Institute of Pharmaceutical Biology and Biotechnology, Heinrich-Heine University, 40225 Duesseldorf, Germany; E-Mail: proksch@duesseldorf-uni.de

* Author to whom correspondence should be addressed; E-Mail: whlin @ bjmu.edu.cn; Tel.: +86-10-8280-6188; Fax: +86-10-8280-2724.

Received: 1 October 2010; in revised form: 18 October 2010 / Accepted: 4 November 2010 / Published: 10 November 2010

\begin{abstract}
Chemical examination of a Chinese soft coral Lobophytum pauciflorum resulted in the isolation of five new biscembranoids named lobophytones $\mathrm{O}-\mathrm{S}(\mathbf{1}-\mathbf{5})$ and a new "monomeric" cembrane lobophytone $\mathrm{T}(\mathbf{6})$. The structures of the new compounds were elucidated by interpretation of 1D and 2D NMR (COSY, HSQC, HMBC, and NOESY) spectroscopic data in association with MS and IR data. Lobophytone Q showed significant inhibition against lipopolysaccharide (LPS)-induced nitric oxide (NO) release in mouse peritoneal macrophages, while lobophytones $\mathrm{Q}$ and $\mathrm{T}$ showed inhibitory activities against the bacteria $S$. aureus and $S$. pneumoniae.
\end{abstract}

Keywords: soft coral; Lobophytum pauciflorum; lobophytones O-T; structure elucidation; NO inhibition; antibiotic activity

\section{Introduction}

Biscembranes are a class of marine natural products with unusual structure patterns, which are mainly found in the marine soft coral genus of Sarcophyton (S. tortuosum, S. glaucum, S. latum, and 
S. elegans). They are supposed to be biogenetically derived by a Diels-Alder cycloaddition of cembranoid-diene and cembranoid-dienophile [1-8]. Recently, we found the soft coral Lobophytum pauciflorum also contains a variety of biscembrane analogues, but they presented the structure pattern with antipodal Diels-Alder cycloaddition and were named isobiscembranoids [9]. This finding provided a new marine organism to enrich the chemical diversity of biscembranoids. Our continuing interest in the chemical diversity of this specimen led to the isolation of five new biscembranoids (1-5) and a new monomeric cembrane (6) (Figure 1). This paper reports the structural elucidation of these new compounds and their bioactivity.

Figure 1. Structures of lobophytones O-T (1-6).

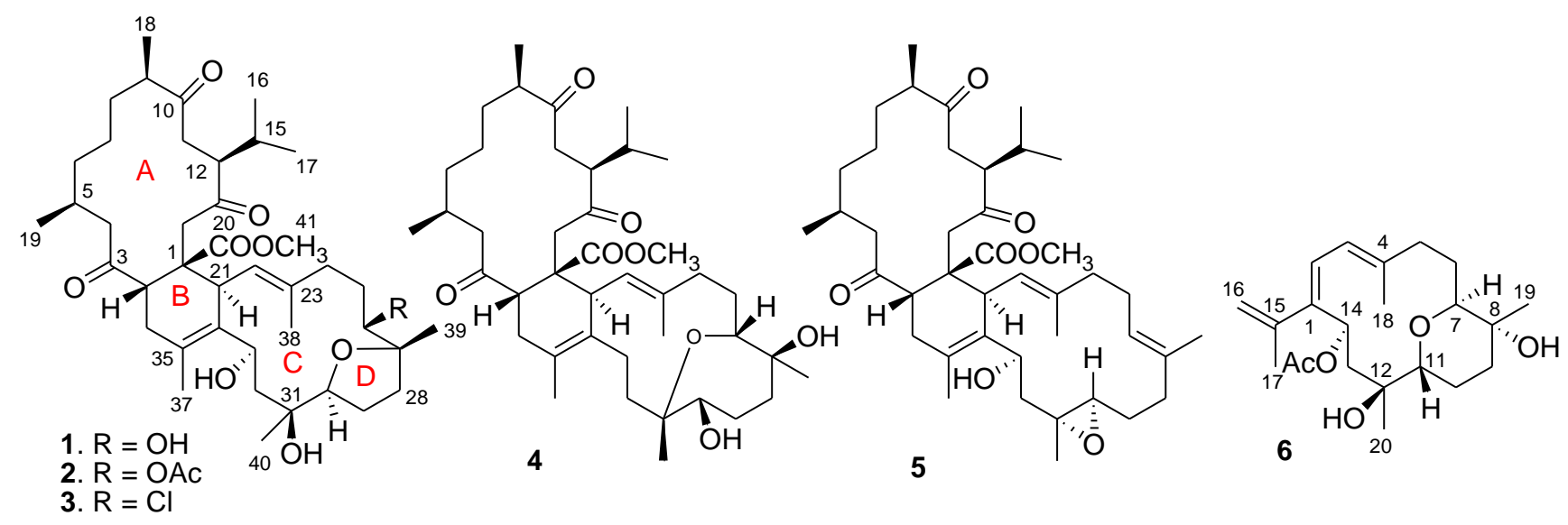

\section{Results and Discussion}

Repeated column chromatography of the EtOAc-soluble fraction obtained from the EtOH extract of the soft coral L. pauciflorum led to the isolation of five biscembranoids and a cembranoid. All biscembranoids shared the partial structure related to methyl tortuosoate, a cembranoid-dienophile [6].

Lobophytone $\mathrm{O}$ (1) has a molecular formula of $\mathrm{C}_{41} \mathrm{H}_{64} \mathrm{O}_{9}$ as determined by HR-ESIMS $m / z 723.4428\left[\mathrm{M}+\mathrm{Na}^{+}\right.$(calcd for $\mathrm{C}_{41} \mathrm{H}_{64} \mathrm{NO}_{9} \mathrm{Na}, 723.4442$ ) and $\mathrm{NMR}$ data, requiring 10 degrees of unsaturation. The ${ }^{1} \mathrm{H}$ NMR spectrum exhibited the resonances for nine methyls including two olefinic methyl singlets $\left(\delta_{\mathrm{H}} 1.65,1.66\right)$ and an $\mathrm{OMe}\left(\delta_{\mathrm{H}} 3.42\right)$, while the ${ }^{13} \mathrm{C}$ NMR spectrum presented 41 carbon resonances including three ketone and one ester carbonyl carbon, four olefinic carbons, and five oxygen-bearing $s p^{3}$ carbons. Six degrees of unsaturation, as accounted by the functional groups out of 10 in the molecule, suggested the presence of a tetracyclic nucleus. The ${ }^{1} \mathrm{H}$ and ${ }^{13} \mathrm{C}$ NMR data of 1 featured a biscembrane skeleton, closely related to that of ximaolide $\mathrm{C}$ as formerly isolated from Sarcophyton tortuosum [3]. COSY in association with HMQC relationships enabled all protons and their corresponding carbons in the molecule to be assigned (Tables 1 and 2). Comparison of NMR data revealed that rings $\mathrm{A}$ and $\mathrm{B}$ of $\mathbf{1}$ were the same as in ximaolide $\mathrm{C}$. The difference was found in ring $\mathrm{C}$, where a hydroxy group of 1 replaced a chlorine atom at C-31 of ximaolide $\mathrm{C}$. This was evident from the presence of a hydroxy proton at $\delta_{\mathrm{H}} 3.98(\mathrm{~s})$, and its HMBC correlations with $\mathrm{C}-30\left(\delta_{\mathrm{C}} 89.2\right)$ and $\mathrm{C}-31\left(\delta_{\mathrm{C}} 73.6\right)$, and by the missing chlorine isotope pattern in the mass spectrum. 
Table 1. ${ }^{13} \mathrm{C}$ NMR data of lobophytones O-S (1-5) $\left(\delta 39.5\right.$, DMSO- $\left.d_{6}\right)$.

\begin{tabular}{|c|c|c|c|c|c|}
\hline Position & 1 & 2 & 3 & 4 & 5 \\
\hline 1 & $49.4(\mathrm{Cq})$ & $49.4(\mathrm{Cq})$ & $49.3(\mathrm{Cq})$ & $48.5(\mathrm{Cq})$ & $49.9(\mathrm{Cq})$ \\
\hline 2 & $43.9(\mathrm{CH})$ & $43.8(\mathrm{CH})$ & $43.9(\mathrm{CH})$ & $45.9(\mathrm{CH})$ & $44.0(\mathrm{CH})$ \\
\hline 3 & $213.8(\mathrm{Cq})$ & $213.8(\mathrm{Cq})$ & $213.8(\mathrm{Cq})$ & $212.1(\mathrm{Cq})$ & $213.9(\mathrm{Cq})$ \\
\hline 4 & $54.1\left(\mathrm{CH}_{2}\right)$ & $54.0\left(\mathrm{CH}_{2}\right)$ & $54.1\left(\mathrm{CH}_{2}\right)$ & $50.4\left(\mathrm{CH}_{2}\right)$ & $53.9\left(\mathrm{CH}_{2}\right)$ \\
\hline 5 & $27.3(\mathrm{CH})$ & $27.3(\mathrm{CH})$ & $27.3(\mathrm{CH})$ & $26.9(\mathrm{CH})$ & $27.3(\mathrm{CH})$ \\
\hline 6 & $38.0\left(\mathrm{CH}_{2}\right)$ & $37.9\left(\mathrm{CH}_{2}\right)$ & $38.0\left(\mathrm{CH}_{2}\right)$ & $37.0\left(\mathrm{CH}_{2}\right)$ & $38.0\left(\mathrm{CH}_{2}\right)$ \\
\hline 7 & $26.0\left(\mathrm{CH}_{2}\right)$ & $26.0\left(\mathrm{CH}_{2}\right)$ & $26.0\left(\mathrm{CH}_{2}\right)$ & $24.4\left(\mathrm{CH}_{2}\right)$ & $26.0\left(\mathrm{CH}_{2}\right)$ \\
\hline 8 & $34.1\left(\mathrm{CH}_{2}\right)$ & $34.0\left(\mathrm{CH}_{2}\right)$ & $34.1\left(\mathrm{CH}_{2}\right)$ & $32.7\left(\mathrm{CH}_{2}\right)$ & $34.1\left(\mathrm{CH}_{2}\right)$ \\
\hline 9 & $47.6(\mathrm{CH})$ & $47.5(\mathrm{CH})$ & $47.7(\mathrm{CH})$ & $46.4(\mathrm{CH})$ & $47.8(\mathrm{CH})$ \\
\hline 10 & $213.3(\mathrm{Cq})$ & $213.3(\mathrm{Cq})$ & $213.3(\mathrm{Cq})$ & $213.6(\mathrm{Cq})$ & $213.1(\mathrm{Cq})$ \\
\hline 11 & $30.9\left(\mathrm{CH}_{2}\right)$ & $31.0\left(\mathrm{CH}_{2}\right)$ & $30.9\left(\mathrm{CH}_{2}\right)$ & $34.9\left(\mathrm{CH}_{2}\right)$ & $30.9\left(\mathrm{CH}_{2}\right)$ \\
\hline 12 & $51.8(\mathrm{CH})$ & $51.8(\mathrm{CH})$ & $51.7(\mathrm{CH})$ & $51.7(\mathrm{CH})$ & $51.3(\mathrm{CH})$ \\
\hline 13 & $210.0(\mathrm{Cq})$ & $209.9(\mathrm{Cq})$ & $209.9(\mathrm{Cq})$ & $211.5(\mathrm{Cq})$ & $210.3(\mathrm{Cq})$ \\
\hline 14 & $45.9\left(\mathrm{CH}_{2}\right)$ & $45.8\left(\mathrm{CH}_{2}\right)$ & $45.9\left(\mathrm{CH}_{2}\right)$ & $46.9\left(\mathrm{CH}_{2}\right)$ & $46.2\left(\mathrm{CH}_{2}\right)$ \\
\hline 15 & $28.7(\mathrm{CH})$ & $28.7(\mathrm{CH})$ & $28.7(\mathrm{CH})$ & $28.8(\mathrm{CH})$ & $28.9(\mathrm{CH})$ \\
\hline 16 & $21.5\left(\mathrm{CH}_{3}\right)$ & $21.5\left(\mathrm{CH}_{3}\right)$ & $21.5\left(\mathrm{CH}_{3}\right)$ & $21.2\left(\mathrm{CH}_{3}\right)$ & $21.5\left(\mathrm{CH}_{3}\right)$ \\
\hline 17 & $17.6\left(\mathrm{CH}_{3}\right)$ & $17.6\left(\mathrm{CH}_{3}\right)$ & $17.6\left(\mathrm{CH}_{3}\right)$ & $18.3\left(\mathrm{CH}_{3}\right)$ & $17.7\left(\mathrm{CH}_{3}\right)$ \\
\hline 18 & $17.6\left(\mathrm{CH}_{3}\right)$ & $17.6\left(\mathrm{CH}_{3}\right)$ & $17.6\left(\mathrm{CH}_{3}\right)$ & $17.1\left(\mathrm{CH}_{3}\right)$ & $17.7\left(\mathrm{CH}_{3}\right)$ \\
\hline 19 & $22.9\left(\mathrm{CH}_{3}\right)$ & $22.9\left(\mathrm{CH}_{3}\right)$ & $22.9\left(\mathrm{CH}_{3}\right)$ & $22.1\left(\mathrm{CH}_{3}\right)$ & $22.8\left(\mathrm{CH}_{3}\right)$ \\
\hline 20 & $174.8(\mathrm{Cq})$ & $174.7(\mathrm{Cq})$ & $174.7(\mathrm{Cq})$ & $173.8(\mathrm{Cq})$ & $174.6(\mathrm{Cq})$ \\
\hline 21 & $43.7(\mathrm{CH})$ & $43.5(\mathrm{CH})$ & $43.7(\mathrm{CH})$ & $50.2(\mathrm{CH})$ & $43.2(\mathrm{CH})$ \\
\hline 22 & $128.6(\mathrm{CH})$ & $129.4(\mathrm{CH})$ & $130.0(\mathrm{CH})$ & $124.6(\mathrm{CH})$ & $124.6(\mathrm{CH})$ \\
\hline 23 & $137.8(\mathrm{Cq})$ & $136.9(\mathrm{Cq})$ & $136.2(\mathrm{Cq})$ & $135.9(\mathrm{Cq})$ & $133.7(\mathrm{Cq})$ \\
\hline 24 & $33.5\left(\mathrm{CH}_{2}\right)$ & $32.9\left(\mathrm{CH}_{2}\right)$ & $34.0\left(\mathrm{CH}_{2}\right)$ & $36.7\left(\mathrm{CH}_{2}\right)$ & $37.3\left(\mathrm{CH}_{2}\right)$ \\
\hline 25 & $33.1\left(\mathrm{CH}_{2}\right)$ & $31.1\left(\mathrm{CH}_{2}\right)$ & $34.8\left(\mathrm{CH}_{2}\right)$ & $24.4\left(\mathrm{CH}_{2}\right)$ & $23.8\left(\mathrm{CH}_{2}\right)$ \\
\hline 26 & $70.4(\mathrm{CH})$ & $73.5(\mathrm{CH})$ & $65.1(\mathrm{CH})$ & $77.8(\mathrm{CH})$ & $125.1(\mathrm{CH})$ \\
\hline 27 & $85.1(\mathrm{Cq})$ & $83.2(\mathrm{Cq})$ & $84.8(\mathrm{Cq})$ & $74.7(\mathrm{Cq})$ & $132.8(\mathrm{Cq})$ \\
\hline 28 & $35.9\left(\mathrm{CH}_{2}\right)$ & $36.1\left(\mathrm{CH}_{2}\right)$ & $36.8\left(\mathrm{CH}_{2}\right)$ & $39.7\left(\mathrm{CH}_{2}\right)$ & $35.6\left(\mathrm{CH}_{2}\right)$ \\
\hline 29 & $28.1\left(\mathrm{CH}_{2}\right)$ & $28.0\left(\mathrm{CH}_{2}\right)$ & $28.0\left(\mathrm{CH}_{2}\right)$ & $27.6\left(\mathrm{CH}_{2}\right)$ & $25.1\left(\mathrm{CH}_{2}\right)$ \\
\hline 30 & $89.2(\mathrm{CH})$ & $89.6(\mathrm{CH})$ & $90.1(\mathrm{CH})$ & $80.0(\mathrm{CH})$ & $59.8(\mathrm{CH})$ \\
\hline 31 & $73.6(\mathrm{Cq})$ & $73.3(\mathrm{Cq})$ & $73.2(\mathrm{Cq})$ & $80.5(\mathrm{Cq})$ & $59.7(\mathrm{Cq})$ \\
\hline 32 & $40.8\left(\mathrm{CH}_{2}\right)$ & $41.5\left(\mathrm{CH}_{2}\right)$ & $40.7\left(\mathrm{CH}_{2}\right)$ & $41.5\left(\mathrm{CH}_{2}\right)$ & $39.6\left(\mathrm{CH}_{2}\right)$ \\
\hline 33 & $64.0(\mathrm{CH})$ & $64.1(\mathrm{CH})$ & $63.9(\mathrm{CH})$ & $24.4\left(\mathrm{CH}_{2}\right)$ & $62.6(\mathrm{CH})$ \\
\hline 34 & $135.6(\mathrm{Cq})$ & $135.2(\mathrm{Cq})$ & $135.2(\mathrm{Cq})$ & $132.8(\mathrm{Cq})$ & $133.1(\mathrm{Cq})$ \\
\hline 35 & $123.2(\mathrm{Cq})$ & $123.2(\mathrm{Cq})$ & $123.6(\mathrm{Cq})$ & $123.3(\mathrm{Cq})$ & $127.6(\mathrm{Cq})$ \\
\hline 36 & $32.5\left(\mathrm{CH}_{2}\right)$ & $32.6\left(\mathrm{CH}_{2}\right)$ & $32.5\left(\mathrm{CH}_{2}\right)$ & $32.1\left(\mathrm{CH}_{2}\right)$ & $32.6\left(\mathrm{CH}_{2}\right)$ \\
\hline 37 & $18.4\left(\mathrm{CH}_{3}\right)$ & $18.4\left(\mathrm{CH}_{3}\right)$ & $18.3\left(\mathrm{CH}_{3}\right)$ & $20.1\left(\mathrm{CH}_{3}\right)$ & $18.7\left(\mathrm{CH}_{3}\right)$ \\
\hline 38 & $20.6\left(\mathrm{CH}_{3}\right)$ & $20.3\left(\mathrm{CH}_{3}\right)$ & $20.2\left(\mathrm{CH}_{3}\right)$ & $17.9\left(\mathrm{CH}_{3}\right)$ & $17.6\left(\mathrm{CH}_{3}\right)$ \\
\hline 39 & $20.3\left(\mathrm{CH}_{3}\right)$ & $20.8\left(\mathrm{CH}_{3}\right)$ & $20.3\left(\mathrm{CH}_{3}\right)$ & $25.4\left(\mathrm{CH}_{3}\right)$ & $17.3\left(\mathrm{CH}_{3}\right)$ \\
\hline 40 & $23.5\left(\mathrm{CH}_{3}\right)$ & $23.4\left(\mathrm{CH}_{3}\right)$ & $23.5\left(\mathrm{CH}_{3}\right)$ & $15.5\left(\mathrm{CH}_{3}\right)$ & $20.3\left(\mathrm{CH}_{3}\right)$ \\
\hline $\mathrm{OMe}$ & $51.2\left(\mathrm{CH}_{3}\right)$ & $51.1\left(\mathrm{CH}_{3}\right)$ & $51.2\left(\mathrm{CH}_{3}\right)$ & $51.0\left(\mathrm{CH}_{3}\right)$ & $51.2\left(\mathrm{CH}_{3}\right)$ \\
\hline \multirow[t]{2}{*}{ Ac } & & $171.3(\mathrm{Cq})$ & & & \\
\hline & & $21.4\left(\mathrm{CH}_{3}\right)$ & & & \\
\hline
\end{tabular}


Table 2. ${ }^{1} \mathrm{H}$ NMR data of lobophytones O-S (1-5) $\left(\delta 2.50\right.$, DMSO- $\left.d_{6}\right)$.

\begin{tabular}{|c|c|c|c|c|c|}
\hline Position & 1 & 2 & 3 & 4 & 5 \\
\hline 2 & $3.47 \mathrm{t}(8.3)$ & $3.45 \mathrm{~m}$ & $3.47 \mathrm{t}(8.8)$ & $3.49 \mathrm{~m}$ & $3.59 \mathrm{t}(8.1)$ \\
\hline \multirow[t]{2}{*}{4} & $3.09 \mathrm{dd}(10.3,19.6)$ & $3.09 \mathrm{dd}(10.3,19.5)$ & $3.09 \mathrm{dd}(10.3,20.0)$ & $2.61 \mathrm{dd}(6.9,17.8)$ & $3.06 \mathrm{dd}(10.3,19.6)$ \\
\hline & $2.40 \mathrm{~d}(19.6)$ & $2.40 \mathrm{~d}(19.5)$ & $2.40 \mathrm{~d}(20.0)$ & $2.32 \mathrm{~m}$ & $2.44 \mathrm{~d}(19.6)$ \\
\hline 5 & $1.68 \mathrm{~m}$ & $1.69 \mathrm{~m}$ & $1.67 \mathrm{~m}$ & $1.85 \mathrm{~m}$ & $1.63 \mathrm{~m}$ \\
\hline \multirow[t]{2}{*}{6} & $1.01 \mathrm{~m}$ & $1.01 \mathrm{~m}$ & $0.97 \mathrm{~m}$ & $1.03 \mathrm{~m}$ & $0.96 \mathrm{~m}$ \\
\hline & $1.07 \mathrm{~m}$ & $1.06 \mathrm{~m}$ & & $0.87 \mathrm{~m}$ & $1.00 \mathrm{~m}$ \\
\hline \multirow[t]{2}{*}{7} & $1.10 \mathrm{~m}$ & $1.12 \mathrm{~m}$ & $1.08 \mathrm{~m}$ & $0.95 \mathrm{~m}$ & $0.94 \mathrm{~m}$ \\
\hline & $1.01 \mathrm{~m}$ & $1.00 \mathrm{~m}$ & $1.00 \mathrm{~m}$ & & $1.07 \mathrm{~m}$ \\
\hline \multirow[t]{2}{*}{8} & $1.43 \mathrm{~m}$ & $1.49 \mathrm{~m}$ & $1.43 \mathrm{~m}$ & $1.40 \mathrm{~m}$ & $1.38 \mathrm{~m}$ \\
\hline & $1.36 \mathrm{~m}$ & $1.35 \mathrm{~m}$ & $1.35 \mathrm{~m}$ & & $1.40 \mathrm{~m}$ \\
\hline 9 & $2.33 \mathrm{~m}$ & $2.33 \mathrm{~m}$ & $2.32 \mathrm{~m}$ & $2.38 \mathrm{~m}$ & $2.30 \mathrm{~m}$ \\
\hline \multirow[t]{2}{*}{11} & $2.80 \mathrm{dd}(10.3,16.6)$ & $2.80 \mathrm{~m}$ & $2.80 \mathrm{dd}(10.5,16.9)$ & $2.73 \mathrm{dd}(2.7,16.9)$ & $1.88 \mathrm{~d}(20.0)$ \\
\hline & $1.84 \mathrm{~d}(16.6)$ & $1.84 \mathrm{~m}$ & $1.83 \mathrm{~d}(16.9)$ & $2.15 \mathrm{dd}(2.4,16.9)$ & $2.82 \mathrm{dd}(10.5,20.0)$ \\
\hline 12 & $2.88 \mathrm{~m}$ & $2.87 \mathrm{~m}$ & $2.89 \mathrm{~m}$ & $2.89 \mathrm{~m}$ & 2.89 brd (10.5) \\
\hline \multirow[t]{2}{*}{14} & $2.86 \mathrm{~d}(19.3)$ & $2.88 \mathrm{~d}(19.3)$ & $2.86 \mathrm{~d}(19.6)$ & $2.96 \mathrm{~m}$ & $2.94 \mathrm{~d}(19.6)$ \\
\hline & $2.72 \mathrm{~d}(19.3)$ & $2.74 \mathrm{~d}(19.3)$ & $2.72 \mathrm{~d}(19.6)$ & $2.90 \mathrm{~m}$ & $2.69 \mathrm{~d}(19.6)$ \\
\hline 15 & $2.33 \mathrm{~m}$ & $2.34 \mathrm{~m}$ & $2.32 \mathrm{~m}$ & $2.07 \mathrm{~m}$ & $2.22 \mathrm{~m}$ \\
\hline 16 & $0.95 \mathrm{~d}(6.7)$ & $0.96 \mathrm{~d}(6.6)$ & $0.95 \mathrm{~d}(6.9)$ & $0.91 \mathrm{~d}(6.9)$ & $0.92 \mathrm{~d}(6.6)$ \\
\hline 17 & $0.63 \mathrm{~d}(6.7)$ & $0.63 \mathrm{~d}(6.6)$ & $0.63 \mathrm{~d}(6.9)$ & $0.71 \mathrm{~d}(6.9)$ & $0.61 \mathrm{~d}(6.6)$ \\
\hline 18 & $1.05 \mathrm{~d}(6.9)$ & $1.05 \mathrm{~d}(6.6)$ & $1.05 \mathrm{~d}(7.0)$ & $1.07 \mathrm{~d}(7.1)$ & $1.04 \mathrm{~d}(6.9)$ \\
\hline 19 & $0.81 \mathrm{~d}(6.9)$ & $0.81 \mathrm{~d}(6.6)$ & $0.81 \mathrm{~d}(6.9)$ & $0.81 \mathrm{~d}(6.9)$ & $0.81 \mathrm{~d}(6.6)$ \\
\hline 21 & $3.38 \mathrm{~d}(10.5)$ & $3.47 \mathrm{~d}(10.3)$ & $3.38 \mathrm{~d}(10.3)$ & $3.23 \mathrm{~m}$ & $3.20 \mathrm{~d}(11.0)$ \\
\hline 22 & $4.78 \mathrm{~d}(10.5)$ & $4.85 \mathrm{~d}(10.3)$ & $4.87 \mathrm{~d}(10.3)$ & $4.94 \mathrm{~d}(11.5)$ & $4.70 \mathrm{~d}(11.0)$ \\
\hline \multirow[t]{2}{*}{24} & $2.02 \mathrm{~m}$ & $2.13 \mathrm{~m}$ & $2.18 \mathrm{~m}$ & $2.38 \mathrm{~m}$ & $2.07 \mathrm{~m}$ \\
\hline & $1.91 \mathrm{~m}$ & $1.51 \mathrm{~m}$ & $1.96 \mathrm{~m}$ & $1.87 \mathrm{~m}$ & $1.92 \mathrm{~m}$ \\
\hline \multirow[t]{2}{*}{25} & $1.65 \mathrm{~m}$ & $1.80 \mathrm{~m}$ & $2.08 \mathrm{~m}$ & $1.82 \mathrm{~m}$ & $2.22 \mathrm{~m}$ \\
\hline & $1.36 \mathrm{~m}$ & $1.60 \mathrm{~m}$ & $1.66 \mathrm{~m}$ & $1.63 \mathrm{~m}$ & $2.00 \mathrm{~m}$ \\
\hline 26 & 3.01 brd (10.5) & $4.56 \mathrm{~d}(10.8)$ & $3.55 \mathrm{~d}(11.7)$ & $3.39 \mathrm{~m}$ & $4.72 \mathrm{br}$ \\
\hline
\end{tabular}


Table 2. Cont

\begin{tabular}{|c|c|c|c|c|c|}
\hline \multirow[t]{2}{*}{28} & $2.25 \mathrm{~m}$ & $1.71 \mathrm{~m}$ & $2.32 \mathrm{~m}$ & $1.58 \mathrm{~m}$ & $2.10 \mathrm{~m}$ \\
\hline & $1.38 \mathrm{~m}$ & $1.45 \mathrm{~m}$ & $1.62 \mathrm{~m}$ & $1.42 \mathrm{~m}$ & $1.91 \mathrm{~m}$ \\
\hline \multirow[t]{2}{*}{29} & $1.67 \mathrm{~m}$ & $1.71 \mathrm{~m}$ & $1.75 \mathrm{~m}$ & $1.85 \mathrm{~m}$ & $1.76 \mathrm{~m}$ \\
\hline & $1.36 \mathrm{~m}$ & $1.43 \mathrm{~m}$ & $1.40 \mathrm{~m}$ & $1.31 \mathrm{~m}$ & $1.47 \mathrm{~m}$ \\
\hline 30 & $3.77 \mathrm{dd}(5.3,10.5)$ & $3.80 \mathrm{dd}(5.1,10.5)$ & $3.86 \mathrm{dd}(5.4,11.5)$ & $2.91 \mathrm{~m}$ & $2.30 \mathrm{~m}$ \\
\hline \multirow[t]{2}{*}{32} & $1.65 \mathrm{~m}$ & $1.71 \mathrm{~m}$ & $1.62 \mathrm{~m}$ & $2.07 \mathrm{~m}$ & $1.96 \mathrm{dd}(10.0,15.4)$ \\
\hline & $1.09 \mathrm{~m}$ & $1.13 \mathrm{~m}$ & $1.09 \mathrm{~m}$ & $1.04 \mathrm{~m}$ & $1.70 \mathrm{dd}(2.0,15.4)$ \\
\hline 33 & $4.80 \mathrm{~m}$ & $4.82 \mathrm{~m}$ & $4.82 \mathrm{brt}$ & $\begin{array}{l}2.10 \mathrm{~m} \\
1.83 \mathrm{~m}\end{array}$ & $4.26 \mathrm{dd}(2.0,10.0)$ \\
\hline \multirow[t]{2}{*}{36} & $2.18 \mathrm{dd}(8.3,19.3)$ & $2.21 \mathrm{dd}(8.8,19.3)$ & $2.21 \mathrm{~m}$ & $2.47 \mathrm{~m}$ & $2.12 \mathrm{~d}(8.1)$ \\
\hline & $2.06 \mathrm{dd}(8.8,19.3)$ & $2.03 \mathrm{~m}$ & $2.05 \mathrm{~m}$ & $1.98 \mathrm{dd}(5.4,18.3)$ & $2.12 \mathrm{~d}(8.1)$ \\
\hline 37 & $1.66 \mathrm{~s}$ & $1.67 \mathrm{~s}$ & $1.67 \mathrm{~s}$ & $1.54 \mathrm{~s}$ & $1.63 \mathrm{~s}$ \\
\hline 38 & $1.65 \mathrm{~s}$ & $1.64 \mathrm{~s}$ & $1.67 \mathrm{~s}$ & $1.69 \mathrm{~s}$ & $1.53 \mathrm{~s}$ \\
\hline 39 & $0.99 \mathrm{~s}$ & $1.09 \mathrm{~s}$ & $1.19 \mathrm{~s}$ & $0.98 \mathrm{~s}$ & $1.52 \mathrm{~s}$ \\
\hline 40 & $0.97 \mathrm{~s}$ & $0.99 \mathrm{~s}$ & $0.99 \mathrm{~s}$ & $0.92 \mathrm{~s}$ & $1.06 \mathrm{~s}$ \\
\hline $\mathrm{OMe}$ & $3.42 \mathrm{~s}$ & $3.39 \mathrm{~s}$ & $3.42 \mathrm{~s}$ & $3.39 \mathrm{~s}$ & $3.40 \mathrm{~s}$ \\
\hline $\mathrm{Ac}$ & & $2.06 \mathrm{~s}$ & & & \\
\hline $\mathrm{OH}-26$ & $4.53 \mathrm{br}$ & & & & \\
\hline $\mathrm{OH}-27$ & & & & $4.18 \mathrm{~s}$ & \\
\hline $\mathrm{OH}-30$ & & & & $4.49 \mathrm{br}$ & \\
\hline $\mathrm{OH}-31$ & $3.98 \mathrm{~s}$ & $4.14 \mathrm{~s}$ & $4.21 \mathrm{~s}$ & & \\
\hline $\mathrm{OH}-33$ & $4.40 \mathrm{br}$ & $4.45 \mathrm{br}$ & $4.46 \mathrm{br}$ & & $4.63 \mathrm{br}$ \\
\hline
\end{tabular}


The relative configurations of the stereogenic centers in $\mathbf{1}$ were determined on the basis of NOE relationships (Figure 2) and $J$ values. The NOE relationship between $\mathrm{H}-2$ ( $\left.\delta_{\mathrm{H}} 3.47\right)$ and OMe suggested cis-conjunction of rings $\mathrm{A}$ and $\mathrm{B}$. The exclusive $\beta$-face of the methyl ester group as found in all known biscembranes led to the biogenetical assignment of the methyl ester at $\mathrm{C}-1$ of $\mathbf{1}$ to be $\beta$-oriented. The obvious NOE correlation between $\mathrm{H}-22\left(\delta_{\mathrm{H}} 4.78\right) / \mathrm{H}-2$ suggested the spatial vicinity of the two protons, thus $\mathrm{H}-21$ was $\alpha$-oriented. The NOE correlations between $\mathrm{H}-21\left(\delta_{\mathrm{H}} 3.38\right) / \mathrm{H}_{3}-38$ $\left(\delta_{\mathrm{H}} 1.65\right), \mathrm{H}_{3}-38 / \mathrm{H}-26\left(\delta_{\mathrm{H}} 3.01\right)$, and $\mathrm{H}_{3}-38 / \mathrm{H}-30\left(\delta_{\mathrm{H}} 3.77\right)$ indicated $\alpha$-orientations of $\mathrm{H}-26$ and $\mathrm{H}-30$, as well as $22 E$ configuration. The $\beta$-orientation of $\mathrm{H}_{3}-39\left(\delta_{\mathrm{H}} 0.99\right)$ was evident from the NOE relationship between $\mathrm{H}-26$ and $\mathrm{H}-28 \mathrm{a}\left(\delta_{\mathrm{H}} 2.25\right)$, which further correlated to $\mathrm{H}-30$, while the assignment of $\mathrm{H}-33 \beta$ was based on the NOE interactions from $\mathrm{OH}-33\left(\delta_{\mathrm{H}} 4.40\right)$ to $\mathrm{H}-21, \mathrm{H}_{3}-38$, and $\mathrm{H}_{3}-40$ (Figure 2). In addition, the NOE relationship between $\mathrm{H}-30 / \mathrm{H}_{3}-40\left(\delta_{\mathrm{H}} 0.97\right)$ suggested $\mathrm{H}_{3}-40$ to be $\alpha$-oriented.

Figure 2. Key NOE correlations of 1, 4-6 related to rings B-D.
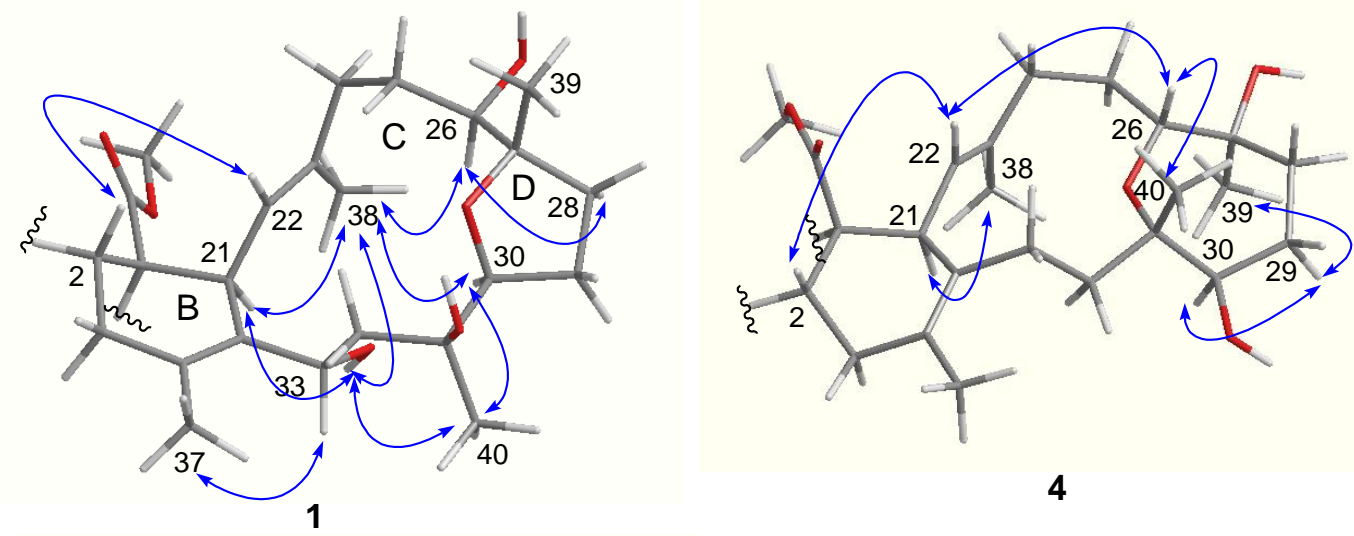

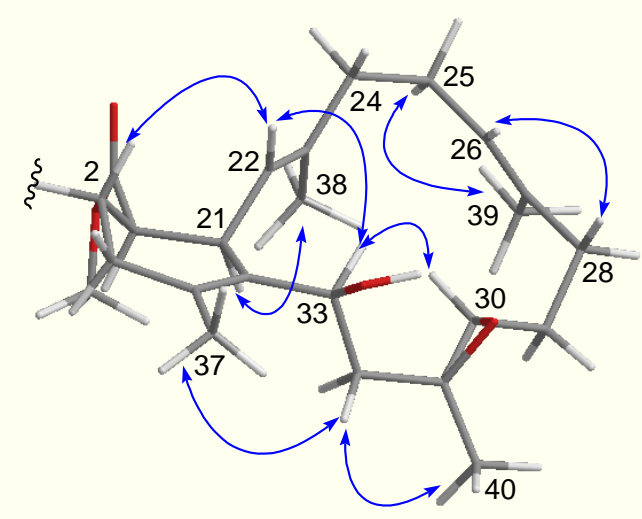

5
4

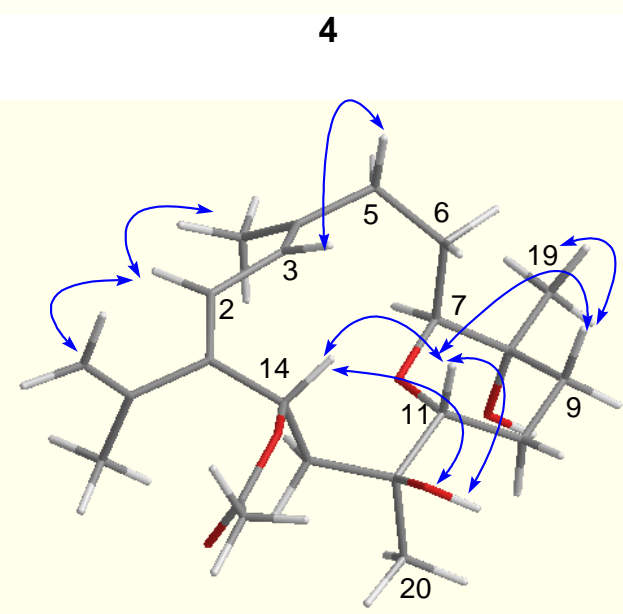

6

Lobophytone $\mathrm{P}$ (2) has a molecular formula of $\mathrm{C}_{43} \mathrm{H}_{66} \mathrm{O}_{10}$ as determined by HR-ESIMS $\left(\mathrm{m} / z 765.4570[\mathrm{M}+\mathrm{Na}]^{+}\right)$, indicating $42 \mathrm{amu}$ more than that of $\mathbf{1}$. Comparison of NMR data revealed that the structure of $\mathbf{2}$ was closely related to that of $\mathbf{1}$, except for the presence of an acetyl group as evident from the ${ }^{13} \mathrm{C}$ NMR signals at $\delta_{\mathrm{C}} 171.3(\mathrm{Cq})$ and $21.4\left(\mathrm{CH}_{3}\right)$ and the corresponding ${ }^{1} \mathrm{H}$ NMR signal at $\delta_{\mathrm{H}} 2.06(3 \mathrm{H}, \mathrm{s})$. The HMBC correlation from $\mathrm{H}-26\left(\delta_{\mathrm{H}} 4.56, \mathrm{~d}, J=10.8 \mathrm{~Hz}\right)$ to the acetyl carbonyl carbon ascertained the location of the acetoxy group at C-26. The similar NOE and NMR 
data of $\mathbf{2}$ and $\mathbf{1}$ indicated that $\mathbf{2}$ shared the same configurations of the stereogenic centers of $\mathbf{1}$. Thus, compound $\mathbf{2}$ was determined to be a C-26 acetylated analogue of $\mathbf{1}$.

Lobophytone Q (3) has a molecular formula of $\mathrm{C}_{41} \mathrm{H}_{63} \mathrm{O}_{8} \mathrm{Cl}$ as determined by HR-ESIMS $\left(\mathrm{m} / \mathrm{z} 741.4096[\mathrm{M}+\mathrm{Na}]^{+}\right.$, calcd 741.4104), indicating 10 degrees of unsaturation and the presence of a chlorine atom. The 1D and 2D NMR spectroscopic analysis revealed that the structure of $\mathbf{3}$ was also closely related to that of $\mathbf{1}$. The presence of two $\mathrm{D}_{2} \mathrm{O}$ exchangeable protons at $\delta_{\mathrm{H}} 4.18$ (s) and 4.46 (br) was attributed to two hydroxy groups, which were deduced to be attached at C-31 and C-33, based on the HMBC interactions from OH-31 $\left(\delta_{\mathrm{H}} 4.18, \mathrm{~s}\right)$ to C-30 $\left(\delta_{\mathrm{C}} 90.1\right), \mathrm{C}-31\left(\delta_{\mathrm{C}} 73.2\right)$ and C-32 $\left(\delta_{\mathrm{C}} 40.7\right)$, and the COSY correlation between $\mathrm{OH}-33\left(\delta_{\mathrm{H}} 4.46, \mathrm{bs}\right)$ and $\mathrm{H}-33\left(\delta_{\mathrm{H}} 4.82\right)$. The chlorine atom of 3 was assumed to be substituted at C-26 according to the upfield-shifted C-26 $\left(\delta_{\mathrm{C}} 65.1\right)$, which showed around $\Delta \delta 5$ less than the same carbon of 1 linked by hydroxy group. The relative configurations of the chiral centers in $\mathbf{3}$ were in agreement with those of $\mathbf{1}$ based on the similar NMR and NOE data.

The molecular formula of lobophytone $\mathrm{R}$ (4) was determined as $\mathrm{C}_{41} \mathrm{H}_{64} \mathrm{O}_{8}$ on the basis of HR-ESIMS $\left(\mathrm{m} / z 685.4670[\mathrm{M}+\mathrm{H}]^{+}\right)$, implying 10 degrees of unsaturation. Comparison of NMR data indicated that $\mathbf{4}$ is a biscembranoid possessing the same partial structure, with respect to rings $\mathrm{A}$ and $\mathrm{B}$, of 1. However, the obvious downfield shifted C-26 $\left(\delta_{\mathrm{C}} 77.8\right)$ and C-31 $\left(\delta_{\mathrm{C}} 80.5\right)$, and the upfield shifted C-27 $\left(\delta_{\mathrm{C}} 74.7\right)$ and C-30 $\left(\delta_{\mathrm{C}} 80.0\right)$, in comparison with the corresponding carbons of $\mathbf{1}$, suggested that 4 contains an ether bridge at C-26/C-31 in ring $\mathrm{C}$ rather than C-27/C-30 ether bond of 1. The HMBC correlation from $\mathrm{H}-26\left(\delta_{\mathrm{H}} 3.39\right)$ to $\mathrm{C}-31$ confirmed this assignment. The COSY correlation between $\mathrm{OH}\left(\delta_{\mathrm{H}} 4.49\right.$, br $) / \mathrm{H}-30\left(\delta_{\mathrm{H}} 2.91\right)$ and the $\mathrm{HMBC}$ relationships from $\mathrm{OH}\left(\delta_{\mathrm{H}} 4.18\right)$ to $\mathrm{C}-26$ and C-27 disclosed two hydroxy groups at C-27 and C-30, respectively. The NOE relationships observed between H-2 $\left(\delta_{\mathrm{H}} 3.49, \mathrm{~m}\right) / \mathrm{H}-22\left(\delta_{\mathrm{H}} 4.94, \mathrm{~d}, J=11.5 \mathrm{~Hz}\right), \mathrm{H}-22 / \mathrm{H}-26$, and $\mathrm{H}-26 / \mathrm{H}_{3}-40\left(\delta_{\mathrm{H}} 0.92\right)$ indicated $\mathrm{H}-26$ and $\mathrm{H}_{3}-40$ to be $\beta$-oriented, while the NOE correlations between $\mathrm{OH}-27\left(\delta_{\mathrm{H}} 4.18\right) / \mathrm{H}-26$, $\mathrm{H}-30\left(\delta_{\mathrm{H}} 2.91, \mathrm{~m}\right) / \mathrm{H}-29 \mathrm{a}\left(\delta_{\mathrm{H}} 1.31, \mathrm{~m}\right)$, and $\mathrm{H}_{3}-39\left(\delta_{\mathrm{H}} 0.98\right) / \mathrm{H}-29 \mathrm{a}$ assigned to $\mathrm{H}_{3}-39 \alpha$ and $\mathrm{H}-30 \alpha$.

Lobophytone $\mathrm{S}$ (5) has a molecular formula of $\mathrm{C}_{41} \mathrm{H}_{62} \mathrm{O}_{7}$, as determined by HR-ESIMS $\left(m / z 689.4384[\mathrm{M}+\mathrm{Na}]^{+}\right)$. The NMR spectroscopic data of $\mathbf{5}$ (Tables 1 and 2) indicated that it is a biscembrane, structurally related to ximaolide A [3], a biscembrane isolated from soft coral Sarcophyton tortuosum. Analysis of the NMR spectroscopic data revealed an additional vinyl group $\left(\delta_{\mathrm{C}} 125.1,132.8\right)$ in ring $\mathrm{C}$ of $\mathbf{5}$, in addition to the double bond located at $\mathrm{C}-22 / \mathrm{C}-23$. This double bond was deduced to be located at C-26/C-27 based on the COSY and HMBC correlations. The carbon resonances of C-30 $\left(\delta_{\mathrm{C}} 59.8, \mathrm{CH}\right)$ and $\mathrm{C}-31\left(\delta_{\mathrm{C}} 59.7, \mathrm{Cq}\right)$ were attributed to epoxy carbons, while a hydroxy group linked to C-33 was confirmed by the HMBC correlations from $\mathrm{H}-33\left(\delta_{\mathrm{H}} 4.26\right.$, dd, $J=2.0,10.0 \mathrm{~Hz})$ to $\mathrm{C}-21$ and $\mathrm{C}-35$ and the COSY relationship between $\mathrm{OH}\left(\delta_{\mathrm{H}} 4.63, \mathrm{br}\right) / \mathrm{H}-33$. The NOE correlations between $\mathrm{H}_{3}-39\left(\delta_{\mathrm{H}} 1.52\right) / \mathrm{H}_{2}-25\left(\delta_{\mathrm{H}} 2.00,2.22\right)$ and $\mathrm{H}-22\left(\delta_{\mathrm{H}} 4.70\right) / \mathrm{H}_{2}-24\left(\delta_{\mathrm{H}} 1.92\right.$, 2.07) were in accordance with $22 E$ and $26 E$ geometries (Figure 2). The NOE relationships of $\mathrm{H}-33 / \mathrm{H}-30\left(\delta_{\mathrm{H}} 2.30, \mathrm{~m}\right), \mathrm{H}-33 / \mathrm{H}-22$, and $\mathrm{H}-22 / \mathrm{H}-2$ led to the assignment of $\beta$-faces of $\mathrm{H}-30$ and $\mathrm{H}-33$ and the trans-configuration of the epoxide group.

Lobophytone $\mathrm{T}$ (6) has a molecular formula of $\mathrm{C}_{22} \mathrm{H}_{34} \mathrm{O}_{5}$ as determined by HR-ESIMS $\left(m / z 401.2292[\mathrm{M}+\mathrm{Na}]^{+}\right)$, implying six degrees of unsaturation. The ${ }^{1} \mathrm{H}$ MMR displayed five methyl singlets including two olefinic methyls at $\delta_{\mathrm{H}} 1.65(3 \mathrm{H}, \mathrm{s})$ and $1.80(3 \mathrm{H}, \mathrm{s})$ and an acetyl methyl group at $\delta_{\mathrm{H}} 1.87(3 \mathrm{H}, \mathrm{s})$, in addition to four olefinic protons for an $\mathrm{AB}$ spin system at $\delta_{\mathrm{H}} 6.02(\mathrm{~d}, J=11.3 \mathrm{~Hz})$ and $6.03(\mathrm{~d}, J=11.3 \mathrm{~Hz})$ and for the exo-methylene at $\delta_{\mathrm{H}} 4.86$ (brs) and 4.82 (brs). The COSY 
correlations established the segments from C-2 to C-3, C-5 to C-7, C-9 to C-11, and C-13 to C-14, while ${ }^{13} \mathrm{C}$ NMR and HMQC data indicated the methines of $\mathrm{C}-7\left(\delta_{\mathrm{C}} 85.0\right), \mathrm{C}-11\left(\delta_{\mathrm{C}} 70.5\right)$ and C-14 $\left(\delta_{\mathrm{C}} 69.7\right)$ bearing oxygen atom. The HMBC relationships connected each segment to form a backbone that featured a cembrane with 14-membered ring. An isopropene was deduced to position at $\mathrm{C}-1$ based on the HMBC cross-peaks from $\mathrm{H}_{2}-16\left(\delta_{\mathrm{H}} 4.86,4.82\right)$ and $\mathrm{H}_{3}-17\left(\delta_{\mathrm{H}} 1.80\right)$ to $\mathrm{C}-1\left(\delta_{\mathrm{C}} 143.5\right)$, while additional HMBC correlations indicated two vinyl groups to be conjugated at $\mathrm{C}-1 / \mathrm{C}-2$ and $\mathrm{C}-3 / \mathrm{C}-4$. The HMBC correlations from $\mathrm{H}_{3}-19\left(\delta_{\mathrm{H}} 1.01\right)$ to $\mathrm{C}-7, \mathrm{C}-8\left(\delta_{\mathrm{C}} 69.2, \mathrm{Cq}\right)$, and $\mathrm{C}-9\left(\delta_{\mathrm{C}} 32.2\right)$, and from $\mathrm{H}_{3}-20\left(\delta_{\mathrm{H}} 1.05\right)$ to $\mathrm{C}-11, \mathrm{C}-12\left(\delta_{\mathrm{C}} 73.7, \mathrm{Cq}\right)$, and $\mathrm{C}-13\left(\delta_{\mathrm{C}} 44.3\right)$, in addition to the HMBC relationship from $\mathrm{H}-7\left(\delta_{\mathrm{H}} 3.26\right)$ to $\mathrm{C}-11$ established an ether bridge which linked $\mathrm{C}-7$ and $\mathrm{C}-11$. The acetoxy group was deduced to position at $\mathrm{C}-14$ on the basis of the HMBC correlations from $\mathrm{H}-14\left(\delta_{\mathrm{H}} 6.01\right)$ to the acetyl carbonyl carbon and to C-1, C-2, and also C-15 ( $\left.\delta_{\mathrm{C}} 144.2, \mathrm{Cq}\right)$. Thus, C-8 and C-12 were hydroxylated, and the gross structure of 6 was established as shown in Figure 1. The relative configurations of the chiral centers in $\mathbf{6}$ were determined through $J$ values and NOESY analysis. The coupling constants of $\mathrm{H}-11\left(\delta_{\mathrm{H}} 3.71, \mathrm{dd}, J=2.7,11.7 \mathrm{~Hz}\right)$ suggested its axial orientation in the chair-conformation of the perhydropyrano ring, while the NOE relationship between $\mathrm{H}-11 / \mathrm{H}-14$ indicated the same face ( $\beta$-orientation) of both protons. The NOE interactions of $\mathrm{OH}-12\left(\delta_{\mathrm{H}} 4.03, \mathrm{~s}\right)$ with $\mathrm{H}-11$ and $\mathrm{H}-14$ assigned to $\mathrm{OH}-12 \beta$, whereas the NOESY cross-peaks between $\mathrm{H}-11 / \mathrm{H}-9 \mathrm{a}$ $\left(\delta_{\mathrm{H}} 1.50, \mathrm{~m}\right), \mathrm{H}_{3}-19 / \mathrm{H}-9 \mathrm{a}$, and $\mathrm{H}-7 / \mathrm{OH}-8\left(\delta_{\mathrm{H}} 3.95, \mathrm{~s}\right)$ suggested $\alpha$-orientation for $\mathrm{H}-7$ and $\mathrm{OH}-8$.

The "monomeric" cembrane lobophytone T (6) is likely a precursor (diene) to form the right part of biscembranes when it reacted with methyl tortuosoate [6]. Thus, it provided new evidence to support the plausible biogenetic pathway to generate biscembranes. It is noted that all of the isolated biscembranoids (1-5) maintained the same partial structure of ring A, which was considered to be derived from methyl tortuosoate as a cembranoid-dienophile. The difference was found in ring $\mathrm{C}$ where epoxide rearrangement, oxidation, acetylation, and halogen substitution occurred.

In primary bioassays, compound $\mathbf{3}$ showed significant inhibition against lipopolysaccharide (LPS)-induced nitric oxide (NO) production in mouse peritoneal macrophages with $\mathrm{IC}_{50}=2.8 \mu \mathrm{M}$, whereas the other compounds showed weak activity $\left(\mathrm{IC}_{50}>10 \mu \mathrm{M}\right)$. In addition, all compounds were weakly cytotoxic toward the mouse peritoneal macrophages $\left(\mathrm{IC}_{50}>10 \mu \mathrm{M}\right)$. The antibiotic assay indicated that compounds $\mathbf{3}$ and $\mathbf{6}$ exhibited strong inhibition against Staphylococcus aureus, S. pneumoniae, and Saccharomyces cerevisiae with the inhibitory rates around $90 \%$ at $20 \mu \mathrm{g} / \mathrm{mL}$, but all compounds possessed weakly inhibitory activity against Pseudomonasaerugonisa, Escherichia coli, Candida albicans, and Aspergillus fumigatus.

\section{Experimental Section}

\subsection{General Procedures}

Optical rotations were measured on a Perkin-Elmer 243B polarimeter. IR spectra were determined on a Thermo Nicolet Nexus 470 FTIR spectrometer. ${ }^{1} \mathrm{H}$ and ${ }^{13} \mathrm{C}$ NMR and 2D NMR spectra were recorded on an Avance-500 FT $500 \mathrm{MHz}$ NMR spectrometer using TMS as an internal standard. $\delta$ values are expressed in parts per million (ppm), and $J$ values are reported in Hertz (Hz). HR-ESIMS data were obtained from Bruker APEX IV instrument. Low pressure column chromatography was 
carried out with silica gel (160-200 and 200-300 mesh), and $\mathrm{GF}_{254}$ silica gel for TLC was provided by Qingdao Marine Chemistry Co. Ltd. HPLC chromatography was performed on an Alltech instrument (426-HPLC pump, Alltech UV-vis-200 detector) equipped with Kromasil semipreparative column $(10 \mu \mathrm{m}, \mathrm{ODS}, 10 \mathrm{~mm} \times 250 \mathrm{~mm})$ and YMC-Pack $\mathrm{C}_{8}(5 \mu \mathrm{m}, 10 \mathrm{~mm} \times 250 \mathrm{~mm})$ column.

\subsection{Animal Material}

Soft coral Lobophytum pauciflorum was collected from the inner coral reef at a depth of $10 \mathrm{~m}$ in Sanya Bay, Hainan Island of China, in 2008. Fresh samples were frozen immediately. The specimen was identified by Leen van Ofwegen (National Museum of National History Naturalis). The coral specimen (HSF-6) was deposited at State Key Laboratory of Natural and Biomimetic Drugs, Peking University, China.

\subsection{Extraction and Isolation}

The frozen soft coral L. pauciflorum $(2.3 \mathrm{~kg})$ was homogenized and then extracted with EtOH (twice, $5 \mathrm{~L} /$ each time). The concentrated extract was desalted by dissolving in $\mathrm{MeOH}$ to yield a $\mathrm{MeOH}$ soluble fraction which was concentrated to an oily residue $(92.7 \mathrm{~g})$. This residue was partitioned between $\mathrm{H}_{2} \mathrm{O}$ and EtOAc, and then the water phase was extracted with $n$-BuOH. The EtOAc fraction (12.1 g) was subjected to silica gel (200-300 mesh) column chromatography, eluting with a gradient (petroleum ether-acetone, 20:1, 10:1, 3:1, 1:1) to obtain seven fractions (F1-F7). Fractions F1-F4 mainly contained lipids and steroids, as detected by ${ }^{1} \mathrm{H}$ NMR, while F5 and F6 showed the ${ }^{1} \mathrm{H}$ NMR spectral features of terpenoids. Thus, F5 and F6 were combined (1.69 g) and subsequently subjected to Sephadex LH-20 column eluting with $\mathrm{CH}_{2} \mathrm{Cl}_{2}-\mathrm{MeOH}$ (1:2) to afford 6 portions (P1-P6). P2 (180 mg) showing blue-green spots after spraying with anisaldehyde reagent was further separated on reversed-phase semi-preparative $\mathrm{HPLC}$ with $\mathrm{CH}_{3} \mathrm{CN}-\mathrm{H}_{2} \mathrm{O}(61 \%)$ as a mobile phase to obtain 1 (12.5 mg). P3 (49.2 mg) was separated on ODS HPLC with $\mathrm{MeOH}-\mathrm{H}_{2} \mathrm{O}(82 \%)$ as a mobile phase to afford 4 (7.6 mg), while $2(8.1 \mathrm{mg})$ was obtained from P4 $(40.5 \mathrm{mg})$ by the same separation process as that for P3. Followed by the same process as for P3 and P4, 5 (7.1 mg), 3 (17.7 mg), 3 (14.5 mg), and $6(5.4 \mathrm{mg})$ were separated and purified from P5 $(112.7 \mathrm{mg})$ by reversed-phase semi-preparative HPLC (ODS) with $\mathrm{CH}_{3} \mathrm{CN}-\mathrm{H}_{2} \mathrm{O}(87 \%)$ as a mobile phase.

\subsubsection{Lobophytone O (1)}

Amorphous powder; $[\alpha]_{\mathrm{D}}^{25}+140.4\left(c\right.$ 1.25, $\left.\mathrm{CHCl}_{3}\right)$; IR $(\mathrm{KBr}) v_{\max } 3413,2960,2931,1740,1705$, 1459, 1436, 1386, 1370, 1206, 1086, 1049, $1026 \mathrm{~cm}^{-1} ;{ }^{1} \mathrm{H}$ and ${ }^{13} \mathrm{C}$ NMR data, see Tables 1 and 2; HR-ESIMS $m / z, 723.4428[\mathrm{M}+\mathrm{Na}]^{+}\left(\right.$calcd for $\mathrm{C}_{41} \mathrm{H}_{64} \mathrm{NO}_{9} \mathrm{Na}, 723.4442$ ).

\subsubsection{Lobophytone $\mathrm{P}(\mathbf{2})$}

Amorphous powder; $[\alpha]_{\mathrm{D}}^{25}+133.7\left(c 0.33, \mathrm{CHCl}_{3}\right)$; IR $(\mathrm{KBr}) v_{\max } 3467,2959,2928,1741,1708$, 1459, 1373, 1237, $1028 \mathrm{~cm}^{-1} ;{ }^{1} \mathrm{H}$ and ${ }^{13} \mathrm{C}$ NMR data, see Tables 1 and 2; HR-ESIMS $\mathrm{m} / \mathrm{z}, 765.4570$ $[\mathrm{M}+\mathrm{Na}]^{+}$(calcd for $\mathrm{C}_{43} \mathrm{H}_{66} \mathrm{O}_{10} \mathrm{Na}, 765.4548$ ). 


\subsubsection{Lobophytone Q (3)}

Amorphous powder; $[\alpha]_{\mathrm{D}}^{25}+121.2\left(c\right.$ 1.30, $\left.\mathrm{CHCl}_{3}\right)$; IR $(\mathrm{KBr}) v_{\max } 3440,2958,2930,1741,1706$, 1459, 1374, 1206, $1027 \mathrm{~cm}^{-1} ;{ }^{1} \mathrm{H}$ and ${ }^{13} \mathrm{C}$ NMR data, see Tables 1 and 2; HR-ESIMS $\mathrm{m} / \mathrm{z} 741.4096$ $[\mathrm{M}+\mathrm{Na}]^{+}$(calcd for $\mathrm{C}_{41} \mathrm{H}_{63} \mathrm{O}_{8} \mathrm{NaCl}, 741.4104$ ).

\subsubsection{Lobophytone R (4)}

Amorphous powder; $[\alpha]_{\mathrm{D}}^{25}+151.1\left(c 0.51, \mathrm{CHCl}_{3}\right)$; IR $(\mathrm{KBr}) v_{\max } 3423,2958,2928,1709,1460$, 1376, 1203, $1050 \mathrm{~cm}^{-1} ;{ }^{1} \mathrm{H}$ and ${ }^{13} \mathrm{C}$ NMR data, see Tables 1 and 2; HR-ESIMS $\mathrm{m} / \mathrm{z} 685.4670[\mathrm{M}+\mathrm{H}]^{+}$ (calcd for $\mathrm{C}_{41} \mathrm{H}_{65} \mathrm{O}_{8}, 685.4674$ ).

\subsubsection{Lobophytone $S(\mathbf{5})$}

Amorphous powder; $[\alpha]_{\mathrm{D}}^{25}+101.1\left(c 0.60, \mathrm{CHCl}_{3}\right)$; IR $(\mathrm{KBr}) v_{\max } 3399,2958,2927,1742,1706$, 1459, 1435, 1387, 1204, $1074 \mathrm{~cm}^{-1} ;{ }^{1} \mathrm{H}$ and ${ }^{13} \mathrm{C}$ NMR data, see Tables 1 and 2; HR-ESIMS $m / z 689.4384[\mathrm{M}+\mathrm{Na}]^{+}$(calcd for $\mathrm{C}_{41} \mathrm{H}_{62} \mathrm{O}_{7} \mathrm{Na}, 689.4388$ ).

\subsubsection{Lobophytone $\mathrm{T}(\mathbf{6})$}

Colorless oil; $[\alpha]_{\mathrm{D}}^{25}+36.5\left(c 0.27, \mathrm{CHCl}_{3}\right)$; IR (KBr) $v_{\max } 3423,2969,2935,1734,1453,1375$, 1246, 1071, $1026 \mathrm{~cm}^{-1}$; ${ }^{1} \mathrm{H}$ NMR $\delta$ (ppm, DMSO- $\left.d_{6}\right): 6.02(1 \mathrm{H}, \mathrm{d}, J=11.3 \mathrm{~Hz}, \mathrm{H}-2), 6.03(1 \mathrm{H}, \mathrm{d}$, $J=11.3 \mathrm{~Hz}, \mathrm{H}-3), 2.47$ (1H, m, H-5a), 1.96 (1H, m, H-5b), 1.44 (1H, m, H-6a), 2.00 (1H, m, H-6b), $3.26(1 \mathrm{H}$, brd, $J=8.1 \mathrm{~Hz}, \mathrm{H}-7), 1.42(1 \mathrm{H}, \mathrm{m}, \mathrm{H}-9 \mathrm{a}), 1.50(1 \mathrm{H}, \mathrm{m}, \mathrm{H}-9 \mathrm{~b}), 1.43(1 \mathrm{H}, \mathrm{m}, \mathrm{H}-10 \mathrm{a})$, 1.77 (1H, m, H-10b), 3.71 (1H, dd, $J=2.7,11.7 \mathrm{~Hz}, \mathrm{H}-11), 1.85$ (1H, m, H-13a), 1.97 (1H, m, H-13b), $6.01(1 \mathrm{H}$, brd, $J=10.0 \mathrm{~Hz}, \mathrm{H}-14), 4.82(1 \mathrm{H}, \mathrm{br}, \mathrm{H}-16 \mathrm{a}), 4.86(1 \mathrm{H}, \mathrm{br}, \mathrm{H}-16 \mathrm{~b}), 1.80$ (3H, s, H-17), $1.65(3 \mathrm{H}, \mathrm{s}, \mathrm{H}-18), 1.01$ (3H, s, H-19), $1.05(3 \mathrm{H}, \mathrm{s}, \mathrm{H}-20), 1.87(3 \mathrm{H}, \mathrm{s}, \mathrm{Ac}) ;{ }^{13} \mathrm{C} \mathrm{NMR} \delta(\mathrm{ppm}$, DMSO-d $d_{6}$ : 143.5 (Cq, C-1), 120.5 (CH, C-2), 119.6 (CH, C-3), 137.8 (Cq, C-4), $39.4\left(\mathrm{CH}_{2}, \mathrm{C}-5\right)$, $21.6\left(\mathrm{CH}_{2}, \mathrm{C}-6\right), 85.0(\mathrm{CH}, \mathrm{C}-7), 69.2(\mathrm{Cq}, \mathrm{C}-8), 32.2\left(\mathrm{CH}_{2}, \mathrm{C}-9\right), 19.9\left(\mathrm{CH}_{2}, \mathrm{C}-10\right), 70.5(\mathrm{CH}, \mathrm{C}-11)$, 73.7 (Cq, C-12), $44.3\left(\mathrm{CH}_{2}, \mathrm{C}-13\right), 69.7$ (CH, C-14), 144.2 (Cq, C-15), $114\left(\mathrm{CH}_{2}, \mathrm{C}-16\right), 23.0\left(\mathrm{CH}_{3}\right.$, C-17), $18.1\left(\mathrm{CH}_{3}, \mathrm{C}-18\right), 27.8\left(\mathrm{CH}_{3}, \mathrm{C}-19\right), 25.0\left(\mathrm{CH}_{3}, \mathrm{C}-20\right), 169.9(\mathrm{Cq}, \mathrm{Ac}), 21.5\left(\mathrm{CH}_{3}, \mathrm{Ac}\right)$; HR-ESIMS $m / z, 401.2292[\mathrm{M}+\mathrm{Na}]^{+}$(calcd for $\mathrm{C}_{22} \mathrm{H}_{34} \mathrm{O}_{5} \mathrm{Na}, 401.2298$ ).

\subsection{Assay for Inhibition of Nitric Oxide (NO) Production}

Dexamethasone (DEX, positive control, $20 \mathrm{mM}$ in DMSO) and each compound (20 mM in DMSO) were diluted to $1-20 \mu \mathrm{M}$ range at r.t. before experiment. The final percentage of DMSO in the reaction mixture was less than $0.5 \%(\mathrm{v} / \mathrm{v})$. LPS $(1 \mu \mathrm{g} / \mathrm{mL}), 4 \%$ sodium thioglycolate, RPMI1640, FBS, PBS, MTT and Griess reagents were purchased from Sigma (St. Louis, MO, U.S.). Mouse peritoneal macrophages (PEMФ) were obtained from C57BL6J male mice, and then plated onto 48 well plates and cultured for $2 \mathrm{hrs}$ in DMEM containing 5\% FBS at 5\% $\mathrm{CO}_{2}$ in $37{ }^{\circ} \mathrm{C}$. Mouse PEMФ were incubated with compounds for $1 \mathrm{~h}$ at $37{ }^{\circ} \mathrm{C}$ before stimulation with $1 \mu \mathrm{g} / \mathrm{mL}$ of lipopolysaccharide (LPS) for $24 \mathrm{~h}$. Cells $\left(5 \times 10^{5}\right.$ cells $)$ were preincubated at $37^{\circ} \mathrm{C}$ for $24 \mathrm{~h}$ in serum-free medium and NO production was monitored by measuring nitrite levels in culture media using Griess reagent. 
Absorbance was measured at $548 \mathrm{~nm}$ in incubated media with Griess reagent for $10 \mathrm{~min}$. Viable adherent cells were stained with MTT $(2 \mu \mathrm{g} / \mathrm{mL})$ for $4 \mathrm{~h}$. The medium was then removed and the produced formazan crystals were dissolved in DMSO $(200 \mu \mathrm{L})$. Absorbance was measured at $540 \mathrm{~nm}$.

One-way analysis of variance was applied for all statistical analyses by independent experiments, and data were represented as means \pm standard error of the measurement. Individual values were compared by t-test and a P-value $<0.01$ to evaluate the significant.

\subsection{Antimicrobial and Antifungal Assays}

Antimicrobial and antifungal bioassays were conducted in triplicate following the method as recommended by the National Center for Clinical Laboratory Standards (NCCLS) [10]. The bacterial strains Staphylococcus aureus, S. pneumoniae, Escherichia coli, and Pseudomonas aeruginosa were grown on Mueller-Hinton agar. The yeasts, Candida albicans and Saccharomyces cerevisiae, were grown on Sabouraud dextrose agar, and the fungus, Aspergillus fumigatus, was grown on potato dextrose agar. Targeted microbes (3-4 colonies) were prepared from broth culture (bacteria: $37{ }^{\circ} \mathrm{C}$ for $24 \mathrm{~h}$; fungus: $28^{\circ} \mathrm{C}$ for $48 \mathrm{~h}$ ), and the final spore suspensions of bacteria (in MHB medium), yeasts (in SDB medium), and fungus (in PDB medium) were $10^{6}$ and $10^{5}$ cells $/ \mathrm{mL}$ and $10^{4}$ mycelial fragments/mL, respectively. Testing compounds $(10 \mathrm{mg} / \mathrm{mL}$ as stock solution in DMSO and serial dilutions) were transferred to a 96-well clear plate in triplicate, and the suspension of the test microorganisms were added to each well $(200 \mu \mathrm{L})$ (antimicrobial peptide AMP, streptomycin, and fluconazole were used as positive controls). After incubation, the absorbance at $595 \mathrm{~nm}$ was measured with a microplate reader (TECAN), and the inhibition rate was calculated and plotted versus test concentrations.

\section{Acknowledgements}

This work was supported by the grants from the National Hi-Tech Development Project (863 project) (No. 2010DFA31610, 2007AA09Z448, 2008AA09Z405), NSFC (No. 30930109), National Key Innovation Project (2009ZX09501-014, DYXM-115-02-2-09).

\section{References}

1. Su, J.; Long, K.; Peng, T.; He, C.; Clardy, J. The structure of methyl isosartortuoate, a novel tetracyclic tetraterpenoid from the soft coral Sarcophyton tortuosum. J. Am. Chem. Soc. 1986, 108, 177-178.

2. Kusumi, T.; Igari, M.; Ishitsuka, M.O.; Ichikawa, A.; Itezono, Y.; Nakayama, N.; Kakisawa, H. A novel chlorinated biscembranoid from the marine soft coral Sarcophyton glaucum. J. Org. Chem. 1990, 55, 6286-6289.

3. Leone, P.A.; Bowden, B.F.; Carroll, A.R.; Coll, J.C.; Meehan, G.V. Studies of Australian soft corals, XLIX: A new biscembranoid and its probable biosynthetic precursors from the soft coral Sarcophyton tortuosum. J. Nat. Prod. 1993, 56, 521-526.

4. Zeng, L.; Lan, W.; Su, J.; Zhang, G.; Feng, X.; Liang, Y.; Yang, X. Two new cytotoxic tetracyclic tetraterpenoids from the soft coral Sarcophyton tortuosum. J. Nat. Prod. 2004, 67, 1915-1918. 
5. Iwagawa, T.; Hashimoto, K.; Okamura, H.; Kurawaki, J.; Nakatani, M.; Hou, D.X.; Fujii, M.; Doe, M.; Morimoto, Y.; Takemura, K. Biscembranes from the soft coral Sarcophyton glaucum. J. Nat. Prod. 2006, 69, 1130-1133.

6. Jia, R.; Guo, Y.; Chen, P.; Yang, Y.; Mollo, E.; Gavagnin, M.; Cimino, G. Biscembranoids and their probable biogenetic precursor from the Hainan soft coral Sarcophyton tortuosum. J. Nat. Prod. 2007, 70, 1158-1166.

7. Bishara, A.; Rudi, A.; Benayahu, Y.; Kashman, Y. Three biscembranoids and their monomeric counterpart cembranoid, a biogenetic Diels-Alder precursor, from the soft coral Sarcophyton elegans. J. Nat. Prod. 2007, 70, 1951-1954.

8. Iwagawa, T.; Hashimoto, K.; Yokogawa, Y.; Okamura, H.; Nakatani, M.; Doe, M.; Morimoto, Y.; Takemura, K. Cytotoxic biscembranes from the soft coral Sarcophyton glaucum. J. Nat. Prod. 2009, 72, 946-949.

9. Yan, P.; Lv, Y.; Ofwegen, L.; Proksch, P.; Lin, W. Lobophytones A-G, new isobiscembranoids from the soft coral Lobophytum pauciflorum. Org. Lett. 2010, 12, 2484-2487.

10. Li, E.; Jiang, L.; Guo, L.; Zhang, H.; Che, Y. Pestalachlorides A-C, antifungal metabolites from the plant endophytic fungus Pestalotiopsis adusta. Bioorg. Med. Chem. 2008, 16, 7894-7899.

Samples Availability: Available from the authors.

(C) 2010 by the authors; licensee MDPI, Basel, Switzerland. This article is an open access article distributed under the terms and conditions of the Creative Commons Attribution license (http://creativecommons.org/licenses/by/3.0/). 